\title{
The influence of beliefs and attitudes about antiretroviral treatment on inconsistent condom use in Botswana.
}

\author{
Mpho Keetile ${ }^{1 a}$ \& Gobopamang Letamo ${ }^{b}$ \\ a Department of Population Studies, ${ }^{b}$ Department of Population Studies \\ University of Botswana, Private Bag 00705, Gaborone, Botswana
}

\begin{abstract}
There is little evidence on the influence of attitudes and beliefs of people about ART and inconsistent condom use in Botswana. Using the 2008 Botswana AIDS Impact Survey Data (BAIS III) this study examined the influence of beliefs and attitudes of people about ART on inconsistent use of condoms. A sample of 2087 men and women aged 15-64 years who had ever had sex and had completed BAIS III individual questionnaire were considered for analysis. Bivariate and multivariate analyses were used to explore the relationship between variables of interest. Results have shown that $23 \%$ of respondents held the belief that ARVs cure AIDS. Multivariate analyses have shown positive association between the belief that ARVs cure AIDS (OR, I.2) and inconsistent condom use. Inconsistent condom use was also associated with females (OR, 4.7), no education (OR, I.9) Primary education (OR, 2.1), having ever married (OR, 4.2) and living together (OR, I.07). Results of this study underscore the need for enhanced efforts to consolidate HIV prevention messages and the need for more widespread dissemination of accurate information about ART.
\end{abstract}

Keywords: Botswana, HIV and AIDS, inconsistent, condoms, antiretroviral treatment

\section{Résumé}

II y a peu de preuves sur l'influence des attitudes et croyances du peuple sur I'ART et le préservatif incompatible utilisent au Botswana. À l'aide de la 2008 Botswana AIDS Impact Survey Data (BAIS III) cette étude a examiné l'influence des croyances et des attitudes des individus sur I'ART utilisation incohérente de préservatifs. Un échantillon de 2087 hommes et femmes de 15 à 64 ans, qui avait déjà eu des rapports sexuels et avaient rempli questionnaire individuel BAIS III ont été objet d'une analyse. Des analyses bivariées et multivariées ont été utilisés pour explorer la relation entre variables d'intérêt. Les résultats ont montré que $23 \%$ des répondants ont tenu la croyance qu'ARV guérit le sida. Des analyses multivariées ont montré une association positive entre la croyance que les ARV guérit sida (OR, I.2) et préservatif incompatible utiliser. Préservatif incompatible a également été associé femelles (OR, 4.7), sans instruction $(O R, I, 9)$ enseignement primaire $(O R, 2 . I)$ et ayant jamais marié $(O R, 4.2)$ et vivre ensemble $(O R, I, 07)$. Les résultats de cette étude soulignent la nécessité d'un effort accru consolider les messages de prévention du $\mathrm{VIH}$ et de la nécessité d'une plus large diffusion d'informations exactes sur I'ART.

Mots clés: Botswana, le VIH et le sida, la non-utilisation, les préservatifs, les traitements antirétroviraux

${ }^{1}$ Corresponding Author: mphokeet@yahoo.com ; Phone (+267) 3552711 


\section{Introduction}

Globally, there is a concern that since antiretroviral therapy (ART) became widely available in countries with high HIV prevalence, people who are on ART engage in unsafe sexual practices. Studies in both the developed and developing countries have shown an upward trend in the association between ART availability and unsafe sexual practices (Cohen et al 2009, Cockcroft et al. 2007, Kalichman \& Simbayi 2003). These studies have consistently shown an association between the beliefs and attitudes of people about HIV medications, including ARVs and sexual risky behaviors.

In developed countries, these studies have identified upward trend on sexual risky behaviors since the introduction of ART in the late 1990s (Gremmy and Beltzer 2004; Kalichman and Simbayi 2003; Mah, \& Halperin 2010) including inconsistent condom use. In sub Saharan Africa some studies in countries such as Kenya and Uganda have also shown an increase in sexual risky behaviors since scale up in the provision of ART (Cohen et al. 2009, Gremmy and Beltzer 2004, Abbas et al. 2006 and Sweat et al. 2000). Results of these studies have clearly revealed that consistent beliefs that HIV treatments reduce transmission risks have led to increases in unprotected sexual intercourse. Sweat et al. (2000) argued that enhanced availability of HIV treatment programs, such as the ART program, is likely to facilitate HIV prevention by reducing stigma and increasing HIV testing rates. Abbas et al. (2006) on the other hand argue that an overemphasis on treatment programs could also detract prevention efforts and lead to reduced public concern about HIV/AIDS and increase HIV risk behaviors such as non-use of condoms and multiple sexual partnerships.

Botswana is one of the countries in Sub-Saharan Africa which has been hard hit by the epidemic and has highest prevalence after Swaziland. In the recent past, HIV/AIDS has been the leading cause of morbidity and mortality in Botswana (CSO 2009). The Botswana AIDS Impact Survey III (BAIS III) estimated a national HIV/AIDS prevalence rate of $17.6 \%$ in 2008 compared to $17.1 \%$ in the BAIS II survey of 2004 (CSO 2009). Furthermore Botswana is one of the countries in sub Saharan Africa which has successful ART rollout program (Mazonde 2004). Proper characterization of the influence of the beliefs and attitudes of Batswana men and women about ART on condom use is necessary for policy formulation and prevention of the persistent transmission of HIV/AIDS. This paper explores how certain beliefs and attitudes about ART influence inconsistent use of condoms among people aged 1564 years in Botswana. Information gained from the study will help in providing knowledge which will guide ART education programs. It would also help in making recommendations for promoting more prevention efforts and educating people more about ART.

\section{Theoretical Orientation}

Individual behavior models emphasize the role of individual characteristics in controlling individual behavior. They focus on how individuals control their behaviors and make reasoned actions that impact those decisions (Mberu 2010). Smith (2003), observed that these individual behavior models focus particularly on psychological and cognitive factors believed to influence individual actions and behaviors. The Health Belief Model (HBM) is one leading individual psychological model, which attempts to explain and predict health behaviors and actions by focusing mainly on the attitudes, beliefs and perceptions of individuals (Rosenstock et al. 1974).

HBM has been used over the years to explore various health actions and behaviors, including sexual risk behavior such as inconsistent-use of condoms. The basic argument of this model is the assumption that an individual's characteristics, perceptions, environment and previous experiences are key factors which shape their actions and perceptions of the risks and severity of the outcomes of their behavior (Rosenstock et. al. 1974). It has been adopted to explore a variety of long term and short term behaviors, including sexual risky behavior and the transmission of HIV/AIDS. The HBM contains several constructs that are hypothesized to predict why people engage in prevention, screening, and/or controlling health conditions.

- Personal characteristics, such as age, gender, and ethnicity modify individual perceptions, such as perceived susceptibility, severity, selfefficacy, and benefits \& barriers.

- Perceived susceptibility and severity of a health condition together, have been labelled as "perceived threat."

- Perceived benefits help reduce perceived threat about health behaviour. Perceived barriers impede health behaviours. Benefits minus barriers support health behaviour change.

- Cues in the environment trigger action and act on individual perceptions, such as perceived benefits, and perceived susceptibility. 
Based on the above postulates, this paper adopts a multidimensional approach that considers inconsistent-use of condoms and HIV/AIDS risk perception among individuals who have certain
(PSUs) selected with probability proportional to measures of size (PPS), where measures of size (MOS) were the number of households in the EAs as defined by the 200I Population and Housing Census.

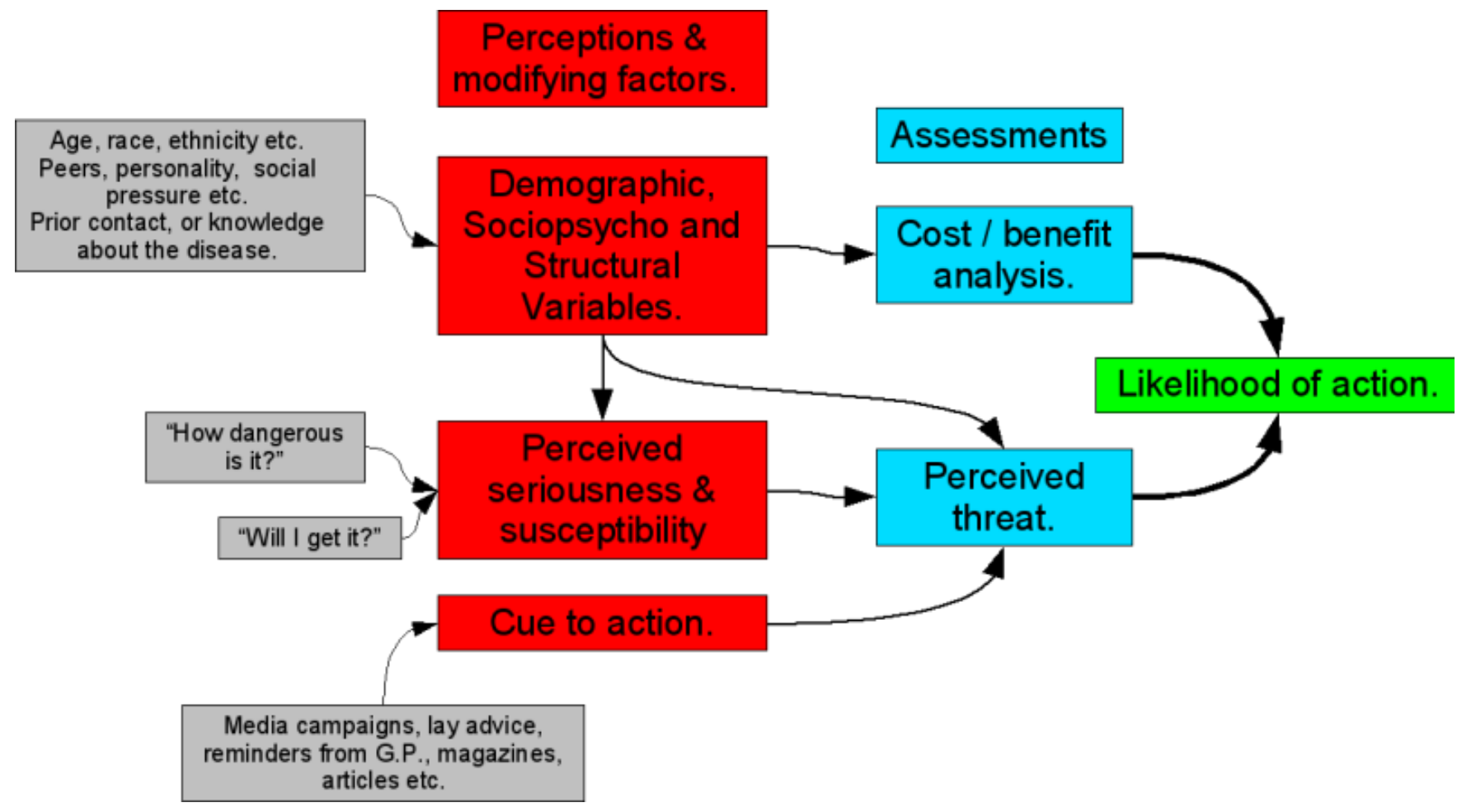

Figure I: The health belief model (Source Banyard 2002)

attitudes and beliefs about ART. Constructs ${ }^{2}$ of the health belief model have been used to inform the nderstanding of the influence of beliefs and attitudes about ART on inconsistent condom use.

\section{Methods \\ Data}

This study used secondary data derived from the 2008 Botswana AIDS Impact Survey III (BAIS III). BAIS III is the third of a series of nationally representative demographic surveys aimed at providing up to date information on the Botswana's HIV and AIDS epidemic. The survey collected information on HIV prevalence; HIV incidence and socio-economic, demographic and behavioral factors that have bearing on HIV transmission, care and support. Botswana Population and Housing Census of $200 \mathrm{I}$ provided the sample frame for BAIS III. This frame consisted of the list of all Enumeration Areas (EA) together with number of households. A stratified two-stage probability sample design was used for the selection of the sample. The first stage was the selection of EAs as Primary Sampling Units

\footnotetext{
${ }^{2}$ Refer to the variable measurement on how constructs have been measured using questions
}

All 460 EAs were selected with probability proportional to size. At the second stage of sampling, the households were systematically selected from a fresh list of occupied households prepared at the beginning of the surveys' fieldwork. Overall, 8380 households were drawn systematically and 7,600 were successfully interviewed, yielding a household response rate of 91 percent (CSO 2009). Within the 7600 completed households 16992 eligible respondents aged 10-64 years were identified out of whom 15,878 were successfully interviewed, yielding an individual response rate of 93 percent. For this study a sample of 2087 men and women aged between 15-64 years who had ever had sex and had successfully completed individual questionnaire were considered for analysis.

\section{Variable Measurement}

BAIS III collected data on background variables and there was the 8-item section which had questions concerning ART related attitudes and beliefs.

\section{Dependent Variable}

Condom use inconsistency was measured by responses to questions that sought to find out if respondents had always used a condom with their 
past three sexual partners. The following questions were used to create a composite index for condom use inconsistency as used in this paper; i) In the past 12 months have you always used a condom with this partner- (partner I-most recent sexual partner) ii) In the past 12 months have you always used a condom with this partner- (partner 2- next most recent sexual partner) and iii) In the past 12 months have you always used a condom with this partner? - (partner 3second most recent sexual partner). A dichotomous composite variable was then derived and used to measure condom use inconsistency. The resultant variable was coded such that I was given to denote condom use inconsistency and 0 to denote that condom has been used consistently with the past three partners.

\section{Independent Variables-}

Some variables informing constructs of the health belief model were used to predict individual sexual behavior (inconsistent-use of condoms) based on attitudes and beliefs about ART.

\begin{tabular}{|c|c|c|c|}
\hline \multicolumn{2}{|c|}{ Construct } & \multicolumn{2}{|c|}{ Question/variables used } \\
\hline i) & Personal characteristics & \multicolumn{2}{|c|}{$\begin{array}{l}\text { Sex, age, education, place of residence, marital status and } \\
\text { religion }\end{array}$} \\
\hline ii) & Perceived susceptibility and severity & $\begin{array}{l}\text { a) } \\
\text { b) }\end{array}$ & $\begin{array}{l}\text { How has your personal concern about getting HIV } \\
\text { changed since the introduction of ARV's? Codes; } \\
\text { I=not concerned, } 2=\text { less concerned \& } 3=\text { more } \\
\text { concerned. } \\
\text { Do you think that there has been a change in } \\
\text { concern about getting HIV among other people in } \\
\text { your community since the introduction of ARV's? } \\
\text { (Coded as above) }\end{array}$ \\
\hline iii) & Perceived benefits & \multicolumn{2}{|c|}{ Do you believe ARVs cure AIDS? Codes $=\mathrm{I}=$ yes $\& 0=$ no } \\
\hline iv) & Perceive barriers & $\begin{array}{l}\text { a) } \\
\text { b) }\end{array}$ & $\begin{array}{l}\text { Do you think that people on ART should always } \\
\text { use condoms. Codes, } I=\text { no } \& 0=y e s \\
\text { Do you think that a person on Antiretroviral (ARV) } \\
\text { should discontinue taking them once they feel } \\
\text { better? Codes } I=\text { yes } \& 0=\text { no }\end{array}$ \\
\hline v) & Cues to action & $\begin{array}{l}\text { a) } \\
\text { b) }\end{array}$ & $\begin{array}{l}\text { Have you ever heard about virus HIV or an illness } \\
\text { called AIDS? Codes, I=yes \& } 0=\text { no } \\
\text { In the past four weeks have you heard or seen any } \\
\text { information about HIV/AIDS? Codes I=yes \& } \\
0=\text { no }\end{array}$ \\
\hline
\end{tabular}

\section{Statistical Method of Analysis}

Bivariate and multivariate analyses were used to identify covariates associated with inconsistent-use of condoms. During bivariate analysis, all socio demographic and some behavioral variables were cross tabulated with the dependent variable to assess their relationships. Logistic regression provides an interpretable linear model for a binary dependent variable. All the predictor variables were entered together into the model in order to test the significance of each predictor while controlling for all other predictors in the model. The data were analyzed using Statistical Package for Social Sciences (SPSS) version 21 program. Results were presented 
in two models, gross effects model and net effects model $\left.\right|^{3}$.

\section{The gross effects model}

Gross effects model examined the relationship between socio-demographic variables, the belief that ARVs cure AIDS and inconsistent condom use. For the gross effects model each of the independent variables was run against the dependent variable. For the association between each independent variable and the dependent variable the model can be expressed as shown below:

$$
y=\alpha+B I+X I^{4}
$$

Where $Y$ is the likelihood that an individual will have sexual intercourse without a condom, $\beta I$ is the baseline constant and $X I$ is an independent variable.

\section{Net effects model}

Net effects model examined the relationship between an independent variable and the dependent variable, while simultaneously controlling for the effects of other variables in the model. Results of the net effects model are more apt compared to those of gross effects model, therefore if there is inconsistency in the results of the two models, the results of the net effects model were adopted. In the net effects model, behavioral variables, moderating for beliefs and attitudes were introduced together with the socio demographic variables to examine how they influence inconsistent-use of condoms. This allowed the prediction of the significance of a given predictor while controlling for all other predictors in the model. The model is as presented below:

$$
Y=\alpha+B I X I+\sum B k X k i^{5}
$$

Whereby $Y$ is the probability that an individual will not use a condom during sexual intercourse. $B I$ is the baseline constant. $X k i$ is an array of $(k)$ independent or control variables and $\beta$ is the corresponding vector of unknown regression coefficients.

\section{Results}

\section{Sample Description}

Table I results indicate that men constituted about two thirds (61.7\%) of the sample. The most dominant age-group was the 20-24 years group which accounted for over one third (38.6\%) and those with secondary education with $61 \%$ of the sample. Almost four fifths (76.7\%) were those who had never married and over one third (64.7\%) were those who professed the Christian religion and all the areas, thus urban, urban villages and rural areas had just over one third of the respondents $(33.7 \%, 33.5 \%$ and $32.8 \%$, respectively).The percentage of population which was aware of antiretroviral treatment was higher $(91.5 \%)$. More than one fifth (23.1\%) of the respondents believed that ARVs cure HIV/ AIDS. More than $90 \%$ of respondents had ever heard about HIV and AIDS, while 6I \% had heard or seen information about HIV/AIDS in the past four weeks.

\footnotetext{
${ }^{3}$ Net effects model results have been used for interpretation since they are more apt than the gross effects.

${ }^{4}$ Source-De Maris (1992)

${ }^{5}$ Source-De Maris (1992
} 
Table I: Sample background Characteristics.

\begin{tabular}{|c|c|c|}
\hline Variable & Number $(\mathrm{N}=2087)$ & Percent \\
\hline \multicolumn{3}{|l|}{ Sex } \\
\hline Male & 1288 & 61.7 \\
\hline Female & 799 & 38.3 \\
\hline \multicolumn{3}{|l|}{ Age } \\
\hline $15-19$ & 307 & 14.7 \\
\hline $20-24$ & 806 & 38.6 \\
\hline $25-29$ & 538 & 25.8 \\
\hline $30-34$ & 217 & 10.4 \\
\hline $35-39$ & 96 & 4.6 \\
\hline $40-44$ & 58 & 2.8 \\
\hline $45-49$ & 25 & 1.2 \\
\hline $50+$ & 38 & 1.8 \\
\hline \multicolumn{3}{|l|}{ Education } \\
\hline No education & 13 & 0.6 \\
\hline Primary & 255 & 12.2 \\
\hline Secondary & 1269 & 60.8 \\
\hline Tertiary & 551 & 26.4 \\
\hline \multicolumn{3}{|l|}{ Marital Status } \\
\hline Never Married & 1601 & 76.7 \\
\hline Ever Married & 100 & 4.8 \\
\hline Living Together & 386 & 18.5 \\
\hline \multicolumn{3}{|l|}{ Religion } \\
\hline Christian & 1352 & 64.7 \\
\hline Other Non-Christian & 722 & 34.6 \\
\hline No Religion & 13 & 0.6 \\
\hline \multicolumn{3}{|l|}{ Place of residence } \\
\hline Urban & 703 & 33.7 \\
\hline Urban villages & 699 & 33.5 \\
\hline Rural areas & 685 & 32.8 \\
\hline \multicolumn{3}{|c|}{ Are you aware about ARVs? } \\
\hline Yes & 1910 & 91.5 \\
\hline No & 177 & 8.5 \\
\hline \multicolumn{3}{|c|}{ Do you believe that ARVs cure HIV/AIDS? } \\
\hline Yes & 482 & 23.1 \\
\hline No & 1605 & 76.9 \\
\hline \multicolumn{3}{|c|}{ Have you ever heard of the virus HIV or an illness called AIDS? } \\
\hline Yes & 1978 & 94.8 \\
\hline No & 109 & 5.2 \\
\hline \multicolumn{3}{|c|}{ In the past four weeks have you heard or seen any information about HIV/AIDS } \\
\hline Yes & 1263 & 60.5 \\
\hline No & 824 & 39.5 \\
\hline
\end{tabular}

\section{Percentage distribution of inconsistent-condom} use by background characteristics

Table 2 results indicate significant association between inconsistent condom use and gender for example almost one quarter (24.2\%) among women respondents did not consistently use condoms. As age increases, inconsistent condom use also increases, for instance $48 \%$ among respondents aged 45-49 years did not use condoms consistently, compared to only II\% among teenagers. Slightly over one third $(30.3 \%)$ of the respondents who had primary education reported inconsistent-use of condoms and just a quarter (25\%) of the respondents who had no education reported inconsistent-use of condoms (compared to 17\% and $22 \%$ among those with secondary and tertiary 
education respectively). About $23 \%$ among rural area inhabitants, reported inconsistent-condom use compared to $17 \%$ among urban villagers and $22 \%$ among urban areas residents. Over $62 \%$ among respondents who were ever married did not use condoms consistently, whereas $27 \%$ among those who said they did not affiliate to any religion did not consistently use condoms.

Table II: Percentage inconsistent-condom use by background characteristics

\begin{tabular}{|c|c|c|c|}
\hline \multicolumn{4}{|c|}{ Condom- used consistently } \\
\hline Variable & Yes & No & Number $(\mathbf{N}=2087)$ \\
\hline \multicolumn{4}{|l|}{ Sex } \\
\hline Male & 82.2 & 17.8 & 1256 \\
\hline \multirow[t]{2}{*}{ Female } & 75.8 & 24.2 & 831 \\
\hline & $X 2=11.296$ & $d f=2$ & $p=0.001$ \\
\hline \multicolumn{4}{|l|}{ Age } \\
\hline $15-19$ & 89.3 & 10.7 & 317 \\
\hline $20-24$ & 83.8 & 16.2 & 848 \\
\hline $25-29$ & 76.4 & 23.6 & 560 \\
\hline $30-34$ & 73.5 & 26.5 & 200 \\
\hline $35-39$ & 54.9 & 45.1 & 91 \\
\hline $40-44$ & 67.4 & 32.6 & 43 \\
\hline $45-49$ & 52.4 & 47.6 & 21 \\
\hline \multirow[t]{2}{*}{$50+$} & 57.1 & 42.9 & 7 \\
\hline & $X 2=182.923$ & $\mathrm{df}=9$ & $p=0.000$ \\
\hline \multicolumn{4}{|l|}{ Education } \\
\hline No education & 75 & 25 & 12 \\
\hline Primary & 69.7 & 30.3 & 208 \\
\hline Secondary & 83.4 & 16.6 & 1248 \\
\hline \multirow[t]{2}{*}{ Tertiary } & 78.5 & 21.5 & 619 \\
\hline & $X 2=120.664$ & $\mathrm{df}=3$ & $p=0.000$ \\
\hline \multicolumn{4}{|l|}{ Place of residence } \\
\hline Urban & 78.3 & 21.7 & 723 \\
\hline Urban villages & 83.4 & 16.6 & 704 \\
\hline \multirow[t]{2}{*}{ Rural areas } & 77.3 & 22.7 & 660 \\
\hline & $X 2=11.249$ & $d f=2$ & $p=0.004$ \\
\hline \multicolumn{4}{|l|}{ Marital Status } \\
\hline Never married & 84.8 & 15.2 & 1550 \\
\hline Ever married & 37.1 & 62.9 & 97 \\
\hline \multirow{2}{*}{ Living together } & 70.8 & 29.2 & 440 \\
\hline & $X 2=73.46 \mid$ & $d f=3$ & $p=0.000$ \\
\hline \multicolumn{4}{|l|}{ Religion } \\
\hline Christian & 80 & 20 & 1356 \\
\hline Other Non-Christian & 79 & 21 & 714 \\
\hline \multirow[t]{2}{*}{ No religion } & 72.8 & 27.3 & 17 \\
\hline & $X 2=2.908$ & $d f=2$ & $p=0.234$ \\
\hline \multicolumn{4}{|c|}{ Are you aware about ARVs? } \\
\hline Yes & 67.6 & 32.4 & 2065 \\
\hline \multirow[t]{2}{*}{ No } & 56.6 & 43.4 & 22 \\
\hline & $X 2=9.476$ & $\mathrm{df}=\mathrm{I}$ & $p=0.002$ \\
\hline \multicolumn{4}{|c|}{ Have you ever heard of the virus HIV or an illness called AIDS? } \\
\hline Yes & 66.7 & 33.3 & 2059 \\
\hline \multirow[t]{2}{*}{ No } & $(48.9)$ & 51.1 & 28 \\
\hline & $\times 2=6.515$ & $d f=I$ & $p=0.011$ \\
\hline \multicolumn{4}{|c|}{ In the past four weeks have you heard or seen any information about HIV/AIDS } \\
\hline Yes & 68.4 & 31.6 & 1617 \\
\hline \multirow[t]{2}{*}{ No } & 63 & 37 & 470 \\
\hline & $X 2=7.205$ & $\mathrm{df}=\mathrm{I}$ & $p=0.007$ \\
\hline
\end{tabular}




\section{Percentage distribution of inconsistent-condom use by beliefs and attitudes towards ART}

Table 3 results indicate that $22 \%$ among the respondents who belief that ARVs cure AIDS did not use condoms consistently and $69 \%$ said that they did not practice safe sex since introduction of ARVs. Among individuals who had the belief that people who are on ART should discontinue them once they feel better over one fifth (22\%) said they did not use condoms consistently (even though the relationship is not significant) and about $21 \%$ among those who held the belief that people on ART should not always use condoms, did not use condoms consistently. Roughly $17 \%$ and $19 \%$ among those not concerned and less concerned about getting HIV since the introduction of ART did not use condoms consistently. Among those who perceived that there has been no community concern and less community concern about getting HIV since the introduction of ART about $21 \%$ and about $22 \%$ respectively reported inconsistent-condom use. More than one fifth $(21 \%)$ of the respondents who had one sexual partner did not use condoms consistently.

Table III: Percentage inconsistent-condom use by beliefs and attitudes towards ART

\begin{tabular}{|c|c|c|c|}
\hline \multirow[t]{2}{*}{ Variable } & \multicolumn{2}{|c|}{ Condom used consistently } & \multirow[b]{2}{*}{ Number $(\mathbf{N}=2087)$} \\
\hline & Yes & No & \\
\hline \multicolumn{4}{|c|}{ Do you believe that ARVs cure HIV/AIDs? } \\
\hline Yes & 78.0 & 22.0 & 327 \\
\hline \multirow[t]{2}{*}{ No } & 80.9 & 19.1 & 1760 \\
\hline & $X^{2}=8.158$ & $d f=I$ & $p=0.004$ \\
\hline \multicolumn{4}{|c|}{ Do you still practice safe sex since the introduction of ART? } \\
\hline Yes & 70.8 & 29.2 & 1191 \\
\hline \multirow[t]{2}{*}{ No } & 30.9 & 69.1 & 897 \\
\hline & $X^{2}=94.205$ & $d f=I$ & $p=0.000$ \\
\hline \multicolumn{4}{|c|}{ Do you believe that a person on ARVs should discontinue/stop taking them once they feel better? } \\
\hline Yes & 78.0 & 22.0 & 328 \\
\hline \multirow[t]{2}{*}{ No } & 80.9 & 19.1 & 1759 \\
\hline & $X^{2}=0.026$ & $d f=I$ & $p=0.872$ \\
\hline \multicolumn{4}{|c|}{ Do you think People on ARVs should always use condom } \\
\hline Yes & 81.3 & 19.7 & 2030 \\
\hline \multirow[t]{2}{*}{ No } & 78.9 & 21.1 & 57 \\
\hline & $X^{2}=1.545$ & $d f=I$ & $p=0.214$ \\
\hline \multicolumn{4}{|c|}{ How has your personal concern about getting HIV change since introduction of ART? } \\
\hline Not concerned & 82.7 & 17.3 & 150 \\
\hline Less concerned & 81.5 & 18.5 & 599 \\
\hline \multirow[t]{2}{*}{ More concerned } & 80.3 & 19.7 & 1338 \\
\hline & $X^{2}=11.545$ & $d f=3$ & $p=0.000$ \\
\hline \multicolumn{4}{|c|}{$\begin{array}{l}\text { Do you think there has been change in concern about getting HIV among other people in your communit } \\
\text { since the introduction of ARVs? }\end{array}$} \\
\hline Not concerned & 79.3 & 20.7 & 140 \\
\hline Less concerned & 78.5 & 21.5 & 634 \\
\hline \multirow[t]{2}{*}{ More concerned } & 65.8 & 34.2 & 1313 \\
\hline & $X^{2}=20.525$ & $d f=2$ & $p=0.005$ \\
\hline
\end{tabular}

\section{Logistic regression results}

Gross effects model results on the influence of beliefs and attitudes about ART on inconsistent condom use

Results of the gross effects model show the likelihood of not using a condom during sexual intercourse given an individual's attitudes and beliefs about ART. Results are presented as unadjusted odds ratios (UOR). Table 4 results indicate that individuals who belief that ARVs cure AIDS were 1.3 times $(U O R=1.38 \mathrm{I}, \quad \mathrm{P}<0.00 \mathrm{I})$ more likely to report inconsistent-use of condoms, while those who did not belief that people on ARVs should always use condoms were less likely $(\mathrm{UOR}=0.845, \mathrm{P}<0.0 \mathrm{I})$ to report inconsistent-use of condoms. 
Table IV: Regression coefficients of beliefs and attitudes about ART and inconsistent condom use (Model gross effects model)

\begin{tabular}{|c|c|c|}
\hline Factor & $\begin{array}{c}\text { Gross effects } \\
\text { Model } \\
\text { UOR* }\end{array}$ & 95\% C.I. \\
\hline \multicolumn{3}{|c|}{ Do you belief that ART cure AIDs? } \\
\hline Yes & $1.38 * * *$ & I.II-I.72 \\
\hline No & 1.00 & \\
\hline \multicolumn{3}{|c|}{ Do you still practice safe sex since the introduction of ART? } \\
\hline Yes & 1.00 & \\
\hline No & $0.18^{* * * *}$ & $0.13-0.27$ \\
\hline \multicolumn{3}{|c|}{ Do you believe that a person on ARVs should discontinue/stop taking them once they feel better? } \\
\hline Yes & 0.97 & $0.68-1.39$ \\
\hline No & 1.00 & \\
\hline \multicolumn{3}{|c|}{ Do you think People on ARVs should always use condom } \\
\hline Yes & 1.00 & \\
\hline No & $0.85^{* * *}$ & $0.65-1.10$ \\
\hline \multicolumn{3}{|c|}{$\begin{array}{l}\text { How has your personal concern about getting HIV change since introduction } \\
\text { of ART? }\end{array}$} \\
\hline Not concerned & 0.91 & $0.65-1.27$ \\
\hline Less concerned & $0.84 *$ & $0.69-1.03$ \\
\hline More concerned & 1.000 & \\
\hline \multicolumn{3}{|c|}{$\begin{array}{l}\text { Do you think there has been change in concern about getting HIV among other people in your community } \\
\text { since the introduction of ARVs? }\end{array}$} \\
\hline Not concerned & 0.89 & $0.62-1.28$ \\
\hline Less concerned & 0.99 & $0.81-1.22$ \\
\hline More concerned & 1.00 & \\
\hline
\end{tabular}

Note: ${ }^{*} \mathrm{P}<0.05,{ }^{*} \mathrm{P}<0.0 \mathrm{I} \& \mathrm{P} * * *<0.00 \mathrm{I}, \mathrm{UOR} *$ means Unadjusted Odds Ratios.

Net- effects model on the influence of beliefs and attitudes about ART on inconsistent condom use

In the net effects model the effects of selected independent variables on inconsistent-use of condoms is investigated. Background variables such as sex, age, education etc are used as control variables. Results are presented as adjusted odds ratios (OR). Results show that when introducing control variables, the effect of beliefs and attitudes about ART on inconsistent condom use diminishes. However, respondents who belief that $A R V s$ cure AIDS were more likely $(O R=1.252, P<0.05)$ to report inconsistent condom use. Results further indicate that women were 4.7 times $(O R=4.717$, $\mathrm{P}<0.00 \mathrm{I}$ ) more likely to report inconsistent condom use compared to men. Individuals with no education were $91 \%$ more likely $(O R=1.906, P<0.01)$ to have not used condoms consistently compared to those with tertiary or higher. The odds of inconsistent-use of condoms are significantly higher among ever married $(\mathrm{OR}=4.2 \mathrm{I} 5, \mathrm{P}<0.0 \mathrm{I})$ ) and living together $(\mathrm{OR}=1.072, \mathrm{P}<0.0 \mathrm{I})$ individuals compared to those who were never married. 
Table V: Logistic regression coefficients showing the likelihood that an individual who had certain beliefs and attitudes about ART used condoms inconsistently

\begin{tabular}{|c|c|c|c|c|}
\hline \multirow[t]{2}{*}{ Factor } & \multicolumn{2}{|c|}{ Model I } & \multicolumn{2}{|c|}{ Model II } \\
\hline & Odds Ratio & 95\% C.I. & Odds Ratio & 95\% C.I. \\
\hline \multicolumn{5}{|c|}{ Belief that ARVs cure AIDS } \\
\hline Yes & I.38* & I.II, I.72 & $1.25 *$ & $1.02,1.53$ \\
\hline No & 1.00 & & 1.00 & \\
\hline \multicolumn{5}{|l|}{ Sex } \\
\hline Male & 1.00 & & 1.000 & \\
\hline Female & $1.06 *$ & $0.89,1.26$ & $4.72 * * *$ & $2.73,8.15$ \\
\hline \multicolumn{5}{|l|}{ Age } \\
\hline $15-19$ & $0.03 * * *$ & $0.04,024$ & $0.29 * * *$ & $0.17,0.53$ \\
\hline $20-24$ & $0.04 * *$ & $0.05,0.28$ & $0.45 * * *$ & $0.29,0.7 \mathrm{I}$ \\
\hline $25-29$ & $0.05 * *$ & $0.01,0.40$ & $0.62 *$ & $0.39,0.97$ \\
\hline $30-34$ & $0.08^{*}$ & $0.01,0.6 \mathrm{I}$ & 0.65 & $0.38,1.11$ \\
\hline $35-39$ & 0.13 & $0.02,1.1$ & 0.67 & $0.34,1.29$ \\
\hline $40-44$ & 0.15 & $0.02,1.19$ & 0.77 & $0.33,1.82$ \\
\hline $45-49$ & 0.17 & $0.02,1.54$ & 1.10 & $0.36,3.37$ \\
\hline $50+$ & 1.00 & & 1.00 & \\
\hline \multicolumn{5}{|l|}{ Education } \\
\hline No education & $3.49 *$ & $2.42,5.03$ & $1.91 *$ & $0.91,3.99$ \\
\hline Primary & $2.09 * * *$ & $1.58,2.78$ & $2.19 * *$ & $1.36,3.53$ \\
\hline Secondary & $0.78^{*}$ & $0.64,0.96$ & 0.86 & $0.65,1.15$ \\
\hline Tertiary or higher & & & 1.00 & \\
\hline \multicolumn{5}{|l|}{ Marital status } \\
\hline Never married & 1.00 & & 1.00 & \\
\hline Ever married & $5.19 *$ & $3.30,8.15$ & $4.22 * * *$ & $2.17,8.18$ \\
\hline Living together & $4.34 *$ & $1.85,10.2$ & $1.07^{*}$ & $0.79,1.45$ \\
\hline \multicolumn{5}{|l|}{ Religion } \\
\hline Christian & 1.00 & & 1.00 & \\
\hline Other non-Christian & 1.05 & $0.88,1.26$ & 0.93 & $0.69,1.24$ \\
\hline No religion & 1.38 & $0.95,2.00$ & 0.87 & $0.49,1.54$ \\
\hline \multicolumn{5}{|l|}{ Place of residence } \\
\hline Urban & 1.00 & & 1.00 & \\
\hline Urban villages & 0.89 & $0.73,1.09$ & $0.74 *$ & $0.56,0.99$ \\
\hline Rural areas & 1.25 & $1.02,1.53$ & $1.13 *$ & $0.83,1.54$ \\
\hline \multicolumn{5}{|c|}{ Belief that people on ARVs should discontinue taking them when they feel better } \\
\hline Yes & & & 0.77 & $0.46,1.29$ \\
\hline No & & & 1.00 & \\
\hline \multicolumn{5}{|c|}{ How has your personal concern about getting HIV change since introduction of ART? } \\
\hline Not concerned & & & 0.76 & $0.45,1.28$ \\
\hline Less concerned & & & $0.70 *$ & $0.5 \mathrm{I}, 0.97$ \\
\hline More concerned & & & 1.00 & \\
\hline \multicolumn{5}{|c|}{$\begin{array}{l}\text { Do you think there has been change in concern about getting HIV among other people in your community } \\
\text { since the introduction of ARVs? }\end{array}$} \\
\hline Not concerned & & & 1.08 & $0.69,1.69$ \\
\hline Less concerned & & & 1.11 & $0.82,1.49$ \\
\hline More concerned & & & 1.00 & \\
\hline \multicolumn{5}{|c|}{ Have you ever heard of the virus HIV or an illness called AIDS? } \\
\hline Yes & & & 1.00 & \\
\hline No & & & 0.88 & $0.47,1.35$ \\
\hline \multicolumn{5}{|c|}{ In the past four weeks have you heard or seen any information about HIV/AIDS } \\
\hline Yes & & & 1.00 & \\
\hline No & & & 0.71 & $0.51,0.96$ \\
\hline
\end{tabular}

Note: $* P<0.05, * * P<0.01 \& P * * *<0.001$

Model I- Belief that ARVs cure AIDS and selected background characteristics (Gross effects)

Model II-Beliefs and attitudes about ART and background characteristics (net effects model) 


\section{Discussion}

Botswana has made significant progress in developing prevention and treatment programs. National ART program, MASA which was implemented and rolled out in 2002 by the government of Botswana has significantly scaled up HIV treatment. The scale-up of ART has been supported indelibly by the African Comprehensive HIV/AIDS Partnerships. Support for HIV/AIDS care, including T.B/HIV services and HIV counselling and testing are provided both directly to national programs and through local and international partners.

This study has indicated positive association between the belief that ARVs cure AIDS and inconsistent condom use, like other studies in some settings (See for example, Kalichman et al 2003, Cohen et al 2009, Batenganya et al 2005, Newman and Rodriguez 2005, Wamoyi et al 201 I, and Wester et al. 2005). No significant association was found for other beliefs and attitudes. The study also found that inconsistent-use of condoms was significantly associated with gender, for instance, inconsistent use of condoms was higher among the females than males. Studies on sexual behaviors of men and women have found that women do not have much say on sexual and reproductive decisions (see Fullilove et. al.1990; Gupta 200I; \& Harvey et al. 2002). Cohen et al (2008) found this to be true in Kenya and conjectured that in Kenya, like anywhere else in the world, men are more likely to act on their attitudes and beliefs than women in regards to sexual activity meaning that for women the risk of acquiring HIV may be a marker of their sexual partners beliefs and attitudes rather than their own.

Youth were less likely to have reported inconsistent condom use compared to adults. For young people, especially teenagers, condom use may be more associated with fear of pregnancy rather than contracting HIV. This finding is concomitant with what BAIS III report presented, that the older a person is, the less likely that she/he used a condom during sexual intercourse and that those who had sexual debut at an older age were also less likely to use a condom during that encounter (see BAIS III, Statistical Report pg. 49, 2008). Inconsistent-use of condoms was significantly higher among those who were ever married and those who were living together than among those who were never married and this may be due to the fact that those ever married and those who are living together perceive that since they stay with their partners they 'know' of their status hence there is no need to use condoms consistently.

\section{Conclusion}

The belief that ARVs cure AIDS is associated with inconsistent condom use. There is need for enhanced efforts to consolidate HIV prevention message and for more widespread dissemination of accurate information about ART. There is need for integration of ART-related education with HIV risk-reduction counselling. HIV prevention messages should address changing attitudes and beliefs about HIV and sexual risk-taking now that ART is widely available in the country. Teach women condom negotiation skills.

\section{Limitations of the study}

The analysis presented in this paper is limited in a number of ways. First, the use of secondary data was a limitation. The Botswana AIDS Impact Survey (BAIS III), upon which the analysis is based, did not collect enough information on the subject to allow in-depth analysis. Second, like most demographic surveys, BAIS III did not collect qualitative data that could have provided in-depth understanding and explanation of patterns observed in the quantitative analysis. However, despite these limitations, the data provides important insights into the attitudes and beliefs of Batswana on ART and the influence of these attitudes and beliefs on inconsistent-condom use.

\section{Contribution of Authors}

Author (a) conceived the idea behind this paper, and produced an outline of the manuscript, including analysis plan and methods, preliminary data exploration and transformation, and produced the initial syntax. Author (a) produced and interpreted the initial findings. Both authors worked on the reviewers' comments and revisions on their respective sections of the paper. Author (b) provided guidance and oversight during the revision of the manuscript; this includes verifying that the data analysis methods, techniques are appropriate, and conclusions accurately reflect the source data. Both authors ensured that the manuscript was presented and formatted in accordance with stipulated guidelines; and that original data and syntax have been properly archived.

\section{References}

Abbas U.L., Anderson R.M., \& Mellows J.W. (2006), "Potential impact of antiretroviral therapy on HIVI transmission and AIDS mortality in resource limited settings", Acquir Immune Def Synd.;4I:632-64I.

Bailey RC, Nguti R \& Bukusi EA. (2009) , “ Association of attitudes and beliefs towards antiretroviral therapy with HIV-Seroprevalence in 
the general population of Kisumu", Kenya. PubMed Central Journal, V.4 (3).

Banyard P. (2002): Created in OpenOffice.org Draw, based on Figure 7.2 page 137 of "Psychology in Practice; Health" Philip Banyard, published by Hodder \& Stoughton.

Bateganya M, Colfax G, Shafer LA, Kityo C, Mugyenyi P, Serwadda D, Mayanja H, Bangsberg D.(2005). "Antiretroviral therapy and sexual behavior: a comparative study between antiretroviral -naïve and -experienced patients at an urban HIV/AIDS care and research center in Kampala, Uganda", Kampala, Uganda. AIDS Patient Care STDS; 19:760-768.

Cockcroft A, Anderson N, Milne D, Mokoena T \& Masisi M. (2007). "Community views about routine HIV testing and antiretroviral treatment in Botswana: Signs of progress from a cross sectional study", BMC International Health and Human Rights, 7.

Cohen CR, Montandon M, Carricco AW, Shiboski S, Bostrom A, Obure A, Kwena Z,

CSO (2008), "Botswana AIDS Impact Survey III", Government of Botswana, Government Printers.

CSO (2009), "Statistics Briefs; causes of mortality". Government Printers, Gaborone.

CSO (2008), "Botswana AIDS Impact Survey III (BAIS III)", Ministry of Finance and Development planning. Government Printers, Gaborone.

DeMaris A. (1992). "Logit modeling: practical applications". London: Sage. p87.

Fullilove, M., Fullilove, R., Haynes, K., \& Gross, S. (1990). "Black Women and AIDS

Prevention: A View toward Understanding the Gender Rules". Journal of Sex Research, 27(I), 4765.

Gremmy I \& Beltzer A. (2004). "HIV risk and condom use in the adult heterosexual population between 192 and 200I, return to starting point"? AIDS; 18:805-809.

Gupta, G. R. (200I). "Gender, sexuality, and HIV/AIDS: The what, the why, and the how". SIECUS Report, 29, 6-I2.

Harvey, S., Bird, S., Galavotti, C., Duncan, E., \& Greenberg, D. (2002). "Relationship Power,

Sexual Decision-making and Condom use Among Women at Risk for HIV/STDs".

Women \& Health, 36(4), 69-84.

Kalichman SC \& Simbayi LC, (2003). "HIV testing attitudes, AIDS stigma and voluntary HIV counseling and testing in Black Township in Cape Town, South Africa”. Sex Trasm Inf, 79:442-447.
Kalichman SC, Eaton L, White D, Cherry C, Pope H, Cain D (2007), "Beliefs about treatments for HIV/AIDS and sexual risk behaviors among men who have sex with men,1997-2006", J Acquir Immune Defic, I:38(2): 196-201.

Mah TL, Halperin DT. (2010). "Concurrent sexual partnerships and the HIV epidemic in sub-Saharan Africa: the evidence to move forward". AIDS Behav; 14: II-6.

Mazonde P (2004), "MASA's new dawn taking time"; Future Positive, 2; 21

Mberu B.U. (2010). "Risk perception for HIV/AIDS infection among premarital sexually initiated youth in Nigeria"; African Population Studies Vol. 24, 3,191-192.

Newman L. \& Rodrguez C. (2005). "Challenges when starting antiretroviral treatment".Online:http//thebody.com/bp/winter0 5/starting.html.

Rosentstock I.M., (1974). "Historical Origins of the Health belief Model". Health Education Mongraphs, 2,328-335.

Smith D.J. (2003), "Imagining HIV/AIDS: Morality and perceptions of personal risk in Nigeria", Medical Anthropology 22(4):343-372

Sweat M,Gregorich S., Sangiwa G., Furlonge C \& Balmer D. (2000). "Cost effectiveness of Voluntary HIV-I counseling and testing in reducing sexual transmission of HIV-I in Kenya and Tanzania". Lancet; 356: I I3-I2I.

Wamoyi J., Mboye M.,Seeley j., Biringu., \& Jaffar S.,(20II); "Changes in sexual desires and behaviors of people living with HIV after initiation of ART; Implications for HIV prevention and health promotion". Biomed Central Ltd. I I:633

Wester C., Bussmann H., Avalos A., Ndwapi N.,Gaolatlhe T.,Peter C., Bussmann C., Moffat H., Mazonde P., \& Malik R.G.(2005) Establishment of a public antiretroviral treatment clinic for adults in Botswana: Lessons learned. Harvard school of Public Health. Boston, Massachussets. 40(7): 10414.

Wilson TE, Gore ME, Greenblatt R., Cohen M, Minkoff $\mathrm{H}$, (2004). "Changes in sexual behaviors among HIV-infected women after initiation of HAART”. Am J Public Health; 94: I I4 I-I I 46. 